\title{
ASPEK REPRODUKSI IKAN OSKAR (Amphilophus citrinellus Günther, 1864) DI WADUK IR H. DJUANDA, JAWA BARAT
}

\section{REPRODUCTION ASPECT OF MIDAS CICHLID (Amphilophus citrinellus, Günther 1864) IN IR. H. DJUANDA RESERVOIR, WEST JAVA}

\author{
Prawira A.R.P. Tampubolon ${ }^{1}$, M. F. Rahardjo ${ }^{2}$, Krismono ${ }^{3}$ \\ ${ }^{1}$ Loka Penelitian Perikanan Tuna, Benoa \\ ${ }^{2}$ Departemen Manajemen Sumber Daya Perairan, FPIK, IPB, Bogor \\ ${ }^{3}$ Balai Penelitian Pemulihan dan Konservasi Sumber Daya Ikan, Jatiluhur \\ Teregistrasi I tanggal: 07 Juli 2014; Diterima setelah perbaikan tanggal: 13 Agustus 2015; \\ Disetujui terbit tanggal: 18 Agustus 2015 \\ e-mail: prawira.atmaja@yahoo.co.id
}

\begin{abstract}
ABSTRAK
Ikan oskar (Amphilophus citrinellus) merupakan ikan asing di Waduk Ir. H. Djuanda yang saat ini merupakan ikan yang paling banyak tertangkap di waduk tersebut. Penelitian ini dilakukan pada Oktober 2011-Januari 2012 di Waduk Ir. H. Djuanda, Jawa Barat, dengan tujuan untuk mengetahui beberapa aspek yang berkaitan dengan pemijahan ikan oskar. Contoh ikan ditangkap menggunakan jaring insang. TKG diamati secara visual dan fekunditas dihitung menggunakan metode gravimetrik. Total ikan contoh yang tertangkap selama penelitian berjumlah 460 ekor yang berasal dari enam stasiun pengamatan. Hasil penelitian menunjukkan panjang total dan bobot tubuh ikan berkisar antara 62-210 mm dan 4,81-187,18 gram. Rasio kelamin ikan seimbang. Ukuran ikan jantan dan betina terkecil yang ditemukan matang gonad adalah $125 \mathrm{~mm}$ dan $121 \mathrm{~mm}$. Ikan yang matang gonad paling banyak ditemukan pada bulan Desember untuk ikan betina dan Januari untuk ikan jantan. Fekunditas total berkisar antara 729-3.299 butir. Ikan oskar merupakan ikan pemijah bertahap.
\end{abstract}

KATA KUNCI: Oskar, pemijahan, kematangan gonad, fekunditas

ABSTRACT

Midas cichlid (Amphilophus citrinellus) is an alien species in Ir. H. Djuanda Reservoir which is the most captured fish in the reservoir. This research was held on October 2011-Januari 2012 in Ir. H. Djuanda Reservoir, West Java. The aim of this research was to know some spawning aspects of midas cichlid. Fish were captured using gill nets. Total captured fish were 460 fishes from six observation stations. Total length of the captured fishes ranged from 62-210 mm and body weight is 4.8-187.18 gram. Gonad maturity was determined visually and fecundity was counted using gravimetric method. Sex ratio of mature fish was balanced. The smallest male and female fish which found mature was $125 \mathrm{~mm}$ and $121 \mathrm{~mm}$. Most of the mature fish commonly found in Desember for female and January for male. Total fecundity ranged from 729-3,299 eggs. Midas cichlid was partial spawner.

KEYWORDS: Midas cichlid, spawning, gonad maturity, fecundity

\section{PENDAHULUAN}

Spesies ikan asing di perairan umum belakangan ini merupakan salah satu obyek yang menjadi perhatian para pemerhati sumber daya ikan di Indonesia terkait dengan dampak buruk yang mungkin ditimbulkannya. Masuknya beberapa jenis ikan asing di perairan, tanpa pengelolaan yang baik, dapat menimbulkan gangguan berupa pemangsaan spesies asli (Billman et al. 2011), menekan pertumbuhan dan rekrutmen spesies asli (Albins \& Hixon 2008; Kostecki et al. 2011), menularkan penyakit atau membawa parasit (Uzunova \& Zlatanova 2007; Nico et al. 2011), berkompetisi (Kartamihardja 2008), dan melakukan persilangan (Hänfling et al. 2005) yang dapat menurunkan keanekaragaman hayati ikan asli.
Waduk Ir. H. Djuanda merupakan salah satu waduk di Indonesia yang saat ini menghadapi permasalahan terkait keberadaan spesies ikan asing. Pada awal pembangunannya (1968-1977), terdapat 31 jenis ikan yang terdiri atas 23 spesies ikan asli dan delapan spesies ikan asing (Kartamihardja 2008). Pada kurun waktu 2008-2009, spesies ikan asli yang ditemukan di Waduk Ir. H. Djuanda hanya tinggal delapan spesies (Tjahjo \& Purnamaningtyas, 2011). Keberadaan jumlah spesies dan kelimpahan ikan asing di perairan Waduk Ir. H. Djuanda semakin meningkat. Ikan yang paling banyak tertangkap di waduk ini adalah ikan asing, ikan oskar (Amphilophus citrinellus) (Putri \& Purnamaningtyas 2011). 
Ikan oskar termasuk kelompok ikan siklid (Famili Cichlidae), kelompok ikan asing yang meningkat paling pesat dalam lima tahun terakhir ini di Waduk Ir. H. Djuanda (Hedianto \& Purnamaningtyas 2012a). Ikan-ikan dari Genus Amphilophus bersifat agresif dalam mempertahankan daerah pemijahan dan melindungi anaknya (Lehtonen et al. 2010). Karakter pemijahan yang demikian diduga menjadi salah satu alasan peningkatan populasi ikan oskar di waduk ini.

Ikan oskar tidak memiliki nilai ekonomis yang tinggi di Waduk Ir. H. Djuanda (Hedianto \& Purnamaningtyas 2012b). Karena dominannya, hasil tangkapan ikan di waduk cenderung homogen dan tangkapan ikan yang bernilai ekonomis berkurang. Ikan oskar dianggap telah merugikan nelayan dan harus segera dikendalikan.

Untuk dapat mengendalikan suatu populasi ikan, maka pengetahuan mengenai karakter reproduksi merupakan salah satu hal yang penting. Penelitian ini bertujuan untuk mengetahui hal-hal yang berkaitan dengan pemijahan ikan oskar seperti nisbah kelamin, indeks kematangan gonad, fekunditas, dan pola pemijahan.

\section{METODEPENELITIAN}

Penelitian ini dilaksanakan selama empat bulan dari Oktober 2011 hingga Januari 2012 di Waduk Ir. H. Djuanda, Jatiluhur, Purwakarta, Jawa Barat (Gambar 1). Pengambilan contoh ikan dilakukan di enam stasiun yang ditentukan berdasarkan karakteristik lokasinya (Lampiran 1).

Ikan contoh ditangkap dengan jaring insang berukuran 1", 1,5", 2", 2,5", 3", dan 4". Setiap contoh ikan ditimbang bobot tubuhnya menggunakan timbangan berketelitian 0,01 gram dan diukur panjang totalnya dengan papan pengukur berketelitian $1 \mathrm{~mm}$.

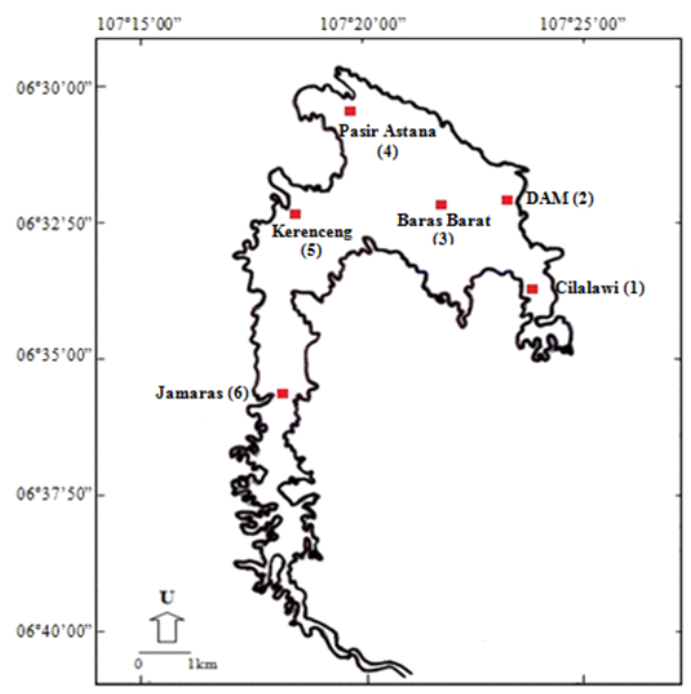

Gambar 1. Peta menunjukan lokasi Waduk Ir. H. Djuanda.

Figure 1. Map showing the location of Ir. H. Djuanda Reservoir.

Ikan dibedah untuk diketahui jenis kelamin dan tingkat kematangan gonadnya. Penentuan jenis kelamin dan tingkat kematangan gonad dilakukan melalui pengamatan morfologis gonad (Tabel 1). Gonad ikan lalu diawetkan di dalam botol sampel yang telah diisi larutan formalin $4 \%$ untuk dianalisis lebih lanjut di Laboratorium Biomakro I, Departemen Manajemen Sumber Daya Perairan, Fakultas Perikanan dan Ilmu Kelautan, Institut Pertanian Bogor.

Nisbah kelamin dianalisis dengan membandingkan antara jumlah ikan jantan dengan jumlah ikan betina yang tertangkap menggunakan persamaan:

$$
x=\frac{J}{B}
$$

Dimana: $\mathrm{X}=$ nisbah kelamin; $\mathrm{J}=$ ikan jantan (ekor); dan $\mathrm{B}=\mathrm{ikan}$ betina (ekor)
Untuk menentukan keseimbangan jenis kelamin, digunakan uji chi kuadrat $\left(X^{2}\right)$ (Supardi 2013) dengan menggunakan persamaan:

$$
x^{2}=\sum \frac{\left(o_{i}-e_{i}\right)^{2}}{e_{i}}
$$

Dimana: $o i=$ frekuensi ikan jantan dan betina yang teramati; dan $e i=$ frekuensi harapan ikan jantan dan ikan betina dalam kondisi seimbang.

Hipotesis yang akan diuji adalah: $\mathrm{H}_{0}$ : Nisbah ikan jantan dan ikan betina adalah seimbang (1:1); dan $\mathrm{H}_{1}$ : Nisbah ikan jantan dan ikan betina tidak seimbang. Apabila nilai $X^{2}$ hitung diperoleh lebih besar daripada $X^{2}$ tabel, maka $\mathrm{H}_{0}$ ditolak yang berarti nisbah kelamin tidak seimbang. 
Tabel 1. Penentuan jenis kelamin dan TKG ikan secara morfologi gonad berdasarkan modifikasi Cassie (Effendie 1979)

Table 1. Determination of sex and gonadal maturity stage morphologically based on Cassie modification (Effendie 1979)

\begin{tabular}{|c|c|c|}
\hline $\begin{array}{c}\text { TKG/ } \\
\text { Maturity } \\
\text { Stage } \\
\end{array}$ & $\begin{array}{l}\text { Morfologi Gonad Jantan/ } \\
\text { Morphology of male gonad }\end{array}$ & $\begin{array}{l}\text { Morfologi Gonad Betina/ } \\
\text { Morphology of female gonad }\end{array}$ \\
\hline I & $\begin{array}{l}\text { Testes seperti benang, lebih pendek dan terlihat } \\
\text { ujungnya di rongga tubuh. Warna jernih. }\end{array}$ & $\begin{array}{l}\text { Ovari seperti benang, panjang sampai ke depan rongga } \\
\text { tubuh. Warna jernih. Permukaan licin. }\end{array}$ \\
\hline II & $\begin{array}{l}\text { Ukuran testes lebih besar. Pewarnaan putih susu. } \\
\text { Bentuk lebih jelas dari TKG I }\end{array}$ & $\begin{array}{l}\text { Ukuran ovari lebih besar. Pewarnaan gelap kekuning- } \\
\text { kuningan. Telur belum terlihat jelas dengan mata. }\end{array}$ \\
\hline III & $\begin{array}{l}\text { Permukaan testes nampak bergerigi. Warna makin } \\
\text { putih, testes makin besar dan dalam keadaan } \\
\text { diawetkan mudah putus. }\end{array}$ & $\begin{array}{l}\text { Ovari bewarna kuning. Secara morfologi telur sudah } \\
\text { kelihatan butirnya dengan mata. }\end{array}$ \\
\hline IV & $\begin{array}{l}\text { Seperti TKG III tampak lebih jelas. Testes makin } \\
\text { pejal. }\end{array}$ & $\begin{array}{l}\text { Ovari makin besar, telur berwarna kuning, mudah } \\
\text { dipisahkan. Butir minyak tidak tampak, mengisi } 1 / 2-2 / 3 \\
\text { rongga tubuh. Usus terdesak. }\end{array}$ \\
\hline V & $\begin{array}{l}\text { Testes bagian belakang kempis dan di bagian dekat } \\
\text { pelepasan masih berisi }\end{array}$ & $\begin{array}{l}\text { Ovari berkerut, dinding tebal, butir telur sisa terdapat } \\
\text { di dekat pelepasan. Banyak telur seperti pada tingkat } \\
\text { II. }\end{array}$ \\
\hline
\end{tabular}

Gonad ikan ditimbang bobotnya untuk menentukan indeks kematangan gonad (IKG) dengan menggunakan persamaan sesuai Effendie (1979):

$$
I K G=\frac{B G}{B T} x 100
$$

Dimana: IKG = indeks kematangan gonad (\%); $\mathrm{BG}=$ bobot gonad (gram); dan BT = bobot tubuh (gram).

Fekunditas dihitung dengan metode gravimetrik. Persamaan untuk menghitung fekunditas sesuai dengan persamaan sesuai Effendie (2002):

$$
F=\frac{G}{Q} x \mathrm{X}
$$

Dimana: $\mathrm{F}=$ fekunditas (butir); $\mathrm{G}=$ bobot gonad (gram); Q = bobot telur contoh (gram); dan $\mathrm{X}=$ jumlah telur contoh (butir).

Selain dihitung, oosit ikan TKG III dan IV juga diukur diameternya. Oosit diambil dari bagian anterior, tengah dan posterior masing-masing 100 butir. Masing-masing oosit diletakkan di atas gelas objek. Selanjutnya diamati dengan metode penyapuan menggunakan mikroskop yang dilengkapi dengan mikrometer okuler yang sebelumnya sudah ditera dengan mikrometer objektif.

\section{HASIL DAN BAHASAN \\ HASIL}

Ikan oskar yang tertangkap selama penelitian berjumlah 460 ekor. Panjang total dan bobot tubuh ikan berkisar antara 62 - $210 \mathrm{~mm}$ dan 4,56- 187,18 gram. Berdasarkan panjangnya, ikan didistribusikan ke dalam 15 kelas dengan interval $10 \mathrm{~mm}$ (Gambar 2).

Frekuensi ikan paling banyak (120 ekor) ditemukan pada selang kelas 101-110 mm; sedangkan yang paling sedikit (2 ekor) adalah pada selang kelas 201-210 mm. Ikan oskar jantan ditemukan dengan ukuran maksimal yang lebih besar daripada ikan betina.

Nisbah kelamin total ikan oskar dan ikan oskar yang siap berpijah (TKG IV) disajikan pada Tabel 2. Nisbah kelamin ikan oskar total adalah 1,24; sedangkan ikan yang siap berpijah adalah 1,08. Setelah dilakukan pengujian proporsi menggunakan uji Khi Kuadrat, diketahui bahwa ikan oskar yang tertangkap memiliki perbandingan jumlah jantan dan betina yang seimbang. 


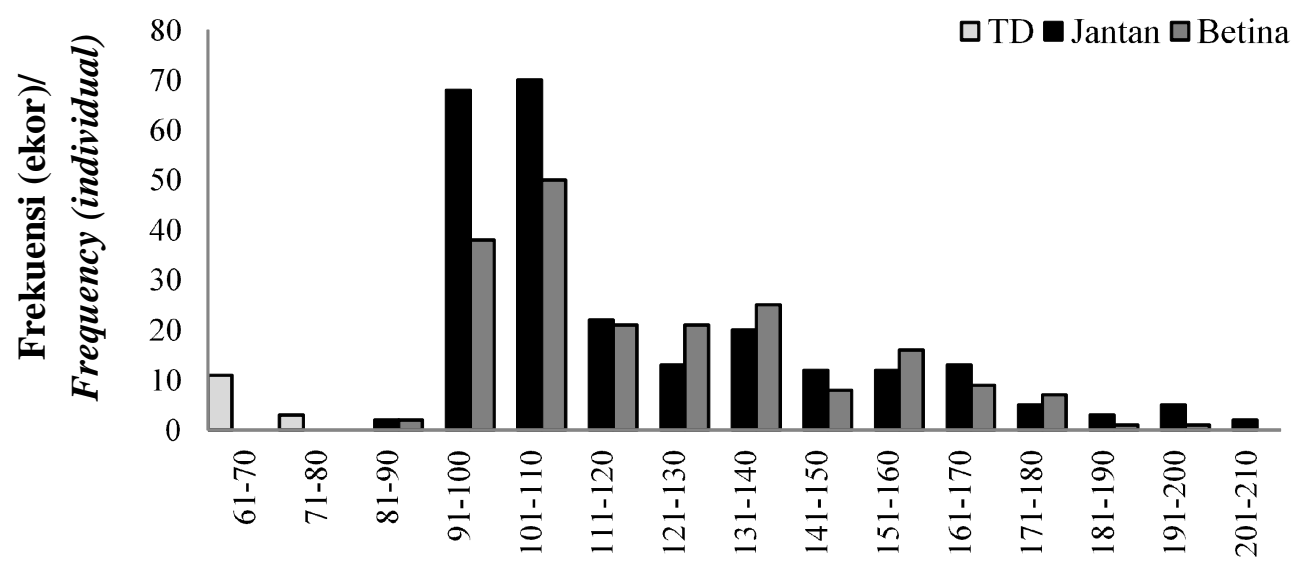

Selang kelas (mm)/ Size interval ( $\mathrm{mm})$

Gambar 2. Distribusi frekuensi kelas ukuran ikan oskar selama penelitian.

Figure 2. Size-frequency distribution of the midas cichlid caught during the research.

Tabel 2. Nisbah kelamin ikan oskar

Table 2. Sex ratio of midas cichlid

\begin{tabular}{lcccccc}
\hline \multirow{2}{*}{ Bulan/ Month } & \multicolumn{3}{c}{ Total/ Total } & \multicolumn{3}{c}{ Siap memijah/ Ready to spawn } \\
\cline { 2 - 7 } & $\begin{array}{c}\text { Jantan/ } \\
\text { Male }\end{array}$ & $\begin{array}{c}\text { Betina/ } \\
\text { Female }\end{array}$ & NK/ & Jantan/ & Betina/ & NK/ \\
Oale & Female & SR \\
\hline Oktober/October & 73 & 52 & 1,40 & 7 & 5 & 1,40 \\
November/ November & 45 & 39 & 1,15 & 5 & 2 & 2,50 \\
Desember/ December & 58 & 58 & 1,00 & 7 & 12 & 0,58 \\
Januari/ January & 71 & 50 & 1,42 & 9 & 7 & 1,29 \\
\hline Total/ Total & 247 & 199 & 1,24 & 28 & 26 & 1,08 \\
\hline
\end{tabular}

Keterangan: $\mathrm{NK}=$ Nisbah kelamin; Note: $S R=$ Sex ratio

Perkembangan gonad ikan oskar diamati secara morfologi. Ikan oskar yang siap berpijah (TKG IV) ditemukan pada pada setiap bulan pengamatan (Gambar 3). Persentase ikan oskar yang telah matang gonad paling

besar ditemukan pada bulan Januari untuk ikan jantan $(21,13)$ dan bulan Desember untuk ikan betina $(39,66)$; sedangkan yang paling kecil pada bulan Oktober untuk ikan jantan $(15,07)$ dan betina $(15,39)$.
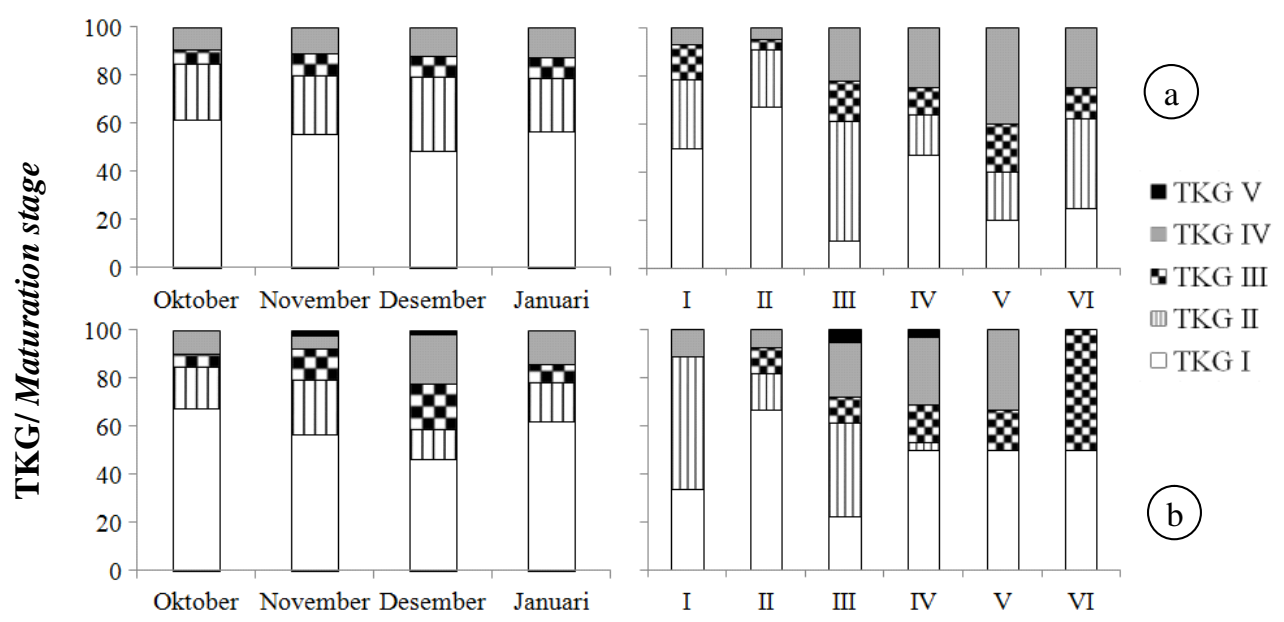

Keterangan/Note:

Waktu pengamatan/Sampling time Stasiun pengamatan/Sampling station

I= Cilalawi; II= Dam; III = Baras Barat; IV= Pasir Astana; V= Kerenceng; VI= Jamaras

Gambar 3. Persentase TKG ikan oskar jantan (a) dan betina (b) berdasarkan bulan pengamatan dan stasiun pengamatan.

Figure 3. Maturation stage percentage of male (a) and female (b) midas cichlid based on sampling time and sampling station. 
Ikan oskar jantan TKG I sampai TKG IV ditemukan di seluruh stasiun pengamatan (Gambar 3). Tidak demikian halnya dengan ikan betina. Ikan betina TKG II tidak ditemukan di Kerenceng (stasiun V) dan Jamaras (stasiun VI); TKG III tidak ditemukan di Stasiun Cilalawi (stasiun I); dan TKG IV tidak ditemukan di Stasiun Jamaras (stasiun VI). Ikan betina TKG V ditemukan di stasiun Baras Barat (stasiun III) dan Pasir Astana (stasiun IV); sedangkan untuk ikan jantan, tidak ditemukan ikan yang ber-TKG V.

Ikan oskar yang matang gonad pertama kali ditemukan pada selang kelas 121-130 mm (Gambar 4). Ikan jantan yang telah matang gonad paling kecil ditemukan pada ukuran
125 mm (TKG III dan TKG IV); sedangkan ikan betina berukuran $121 \mathrm{~mm}$ (TKG III) dan $123 \mathrm{~mm}$ (TKG IV).

IKG ikan oskar menunjukkan nilai yang bervariasi setiap bulannya (Tabel 3). Nilai IKG ikan oskar jantan berkisar antara 0,01-1,18 dan ikan betina berkisar antara 0,01-5,80. Nilai IKG ikan jantan tertinggi pada bulan November dan Januari. Pada ikan betina, nilai IKG tertinggi pada bulan Desember. Nilai IKG terendah untuk ikan jantan dan ikan betina adalah pada bulan Oktober. Fekunditas dihitung pada ikan oskar betina yang sudah mencapai TKG III (23 ekor) dan TKG IV (26 ekor). Fekunditas total berkisar antara 545-3.299 butir dengan rerata 1.647 butir.

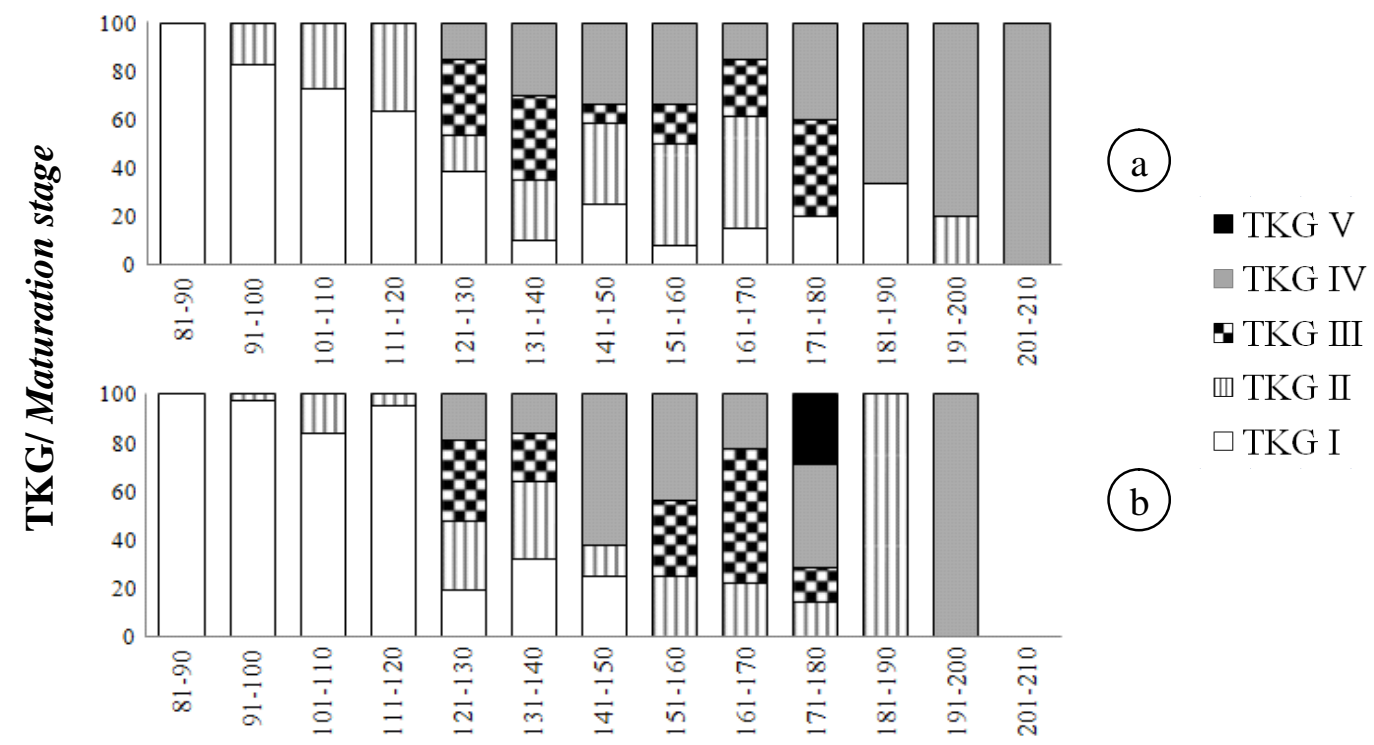

Interval panjang ikan (mm)/ Fish length interval (mm)

Gambar 4. Persentase TKG ikan oskar jantan (a) dan betina (b) berdasarkan kisaran ukuran panjang.

Figure 4. Maturity stage percentage of male (a) and female (b) midas cichlid based on fish length interval.

Tabel 3. Nilai IKG ikan oskar pada setiap bulan pengamatan

Table 3. Gonado somatic index of Midas cichlid during the research

\begin{tabular}{lcccccc}
\hline \multirow{2}{*}{ Bulan/ Month } & \multicolumn{3}{c}{ Jantan/Male } & \multicolumn{3}{c}{ Betina/Female } \\
\cline { 2 - 7 } & $\begin{array}{c}\text { Jumlah/ } \\
\text { Total }\end{array}$ & $\begin{array}{c}\text { Kisaran/ } \\
\text { Range }\end{array}$ & $\begin{array}{c}\text { Rerata/ } \\
\text { Average }\end{array}$ & $\begin{array}{c}\text { Jumlah/ } \\
\text { Total }\end{array}$ & $\begin{array}{c}\text { Kisaran/ } \\
\text { Range }\end{array}$ & $\begin{array}{c}\text { Rerata/ } \\
\text { Average }\end{array}$ \\
\hline Oktober/ October & 73 & $0,01-0,95$ & 0,12 & 52 & $0,01-3,82$ & 0,63 \\
November/ November & 45 & $0,01-1,18$ & 0,14 & 39 & $0,02-4,51$ & 0,66 \\
Desember/ December & 58 & $0,02-0,85$ & 0,13 & 58 & $0,02-5,13$ & 1,16 \\
Januari/ January & 71 & $0,01-1,08$ & 0,14 & 50 & $0,01-3,81$ & 0,70 \\
\hline
\end{tabular}

Hasil pengukuran diameter telur menunjukkan bahwa diameter telur bervariasi antara 0,42-1,17 mm untuk TKG III dan 0,63-1,73 untuk TKG IV. Pola penyebaran diameter telur ikan oskar membentuk dua modus penyebaran (Gambar 5). Pada gambar tersebut terlihat bahwa telur ikan oskar akan semakin besar seiring dengan kematangannya. 

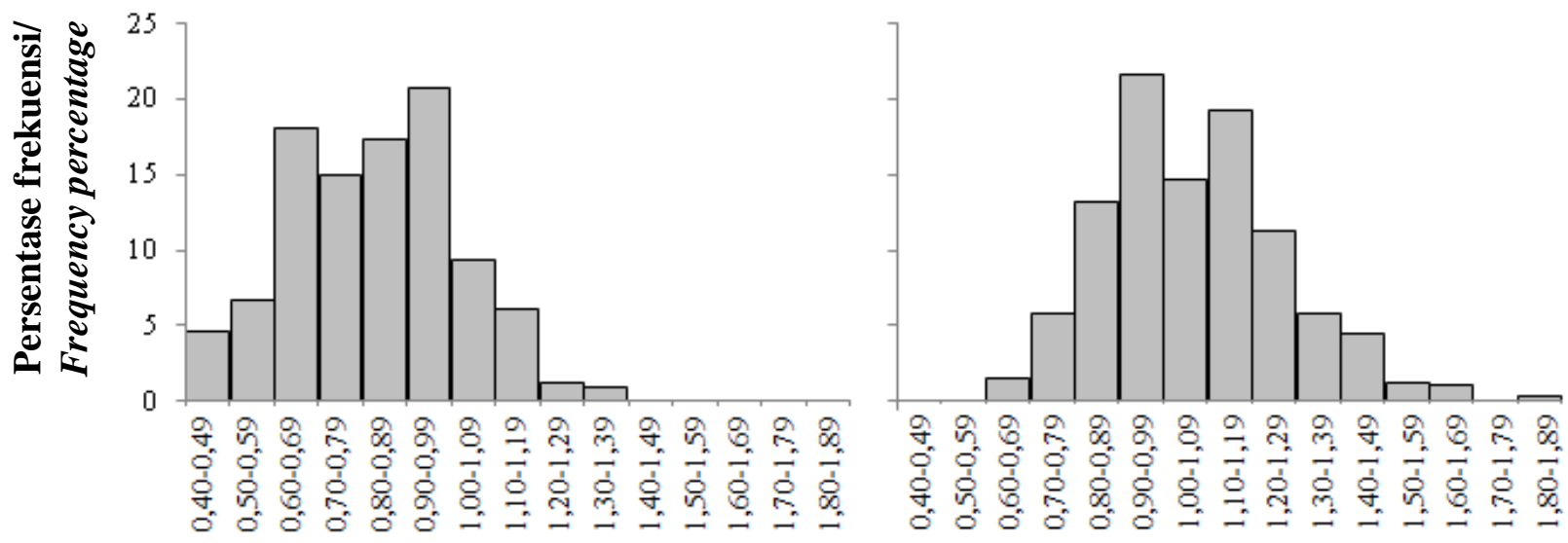

\section{Diameter telur $(\mathbf{m m}) /$ egg diameter $(\mathbf{m m})$}

Gambar 5. Sebaran diameter telur ikan oskar.

Figure 5. Fish egg diameter distribution.

\section{BAHASAN}

Nisbah kelamin ikan oskar secara total dan yang telah matang gonad ada dalam kondisi yang ideal. Ikan jantan dan betina berbanding seimbang (Tabel 2). Keseimbangan ini terkait dengan tingkah laku reproduksi ikan oskar. Ikan oskar merupakan ikan monogamus yang umumnya telah memiliki pasangan tetap sebelum berpijah dengan induk jantan dan betina bersama-sama menjaga telur dan anaknya (biparental care) (Barlow 1976). Nisbah kelamin yang seimbang juga dilaporkan pada ikan Oreochromis niloticus di Waduk Opa, Nigeria (Komolafe \& Arawomo 2007) dan ikan sepat siam di Danau Taliwang (Tampubolon \& Rahardjo 2011) yang melakukan pengasuhan anak.

Pada setiap bulan pengamatan ditemukan ikan oskar yang telah matang gonad (Gambar 3). Demikian juga pada bulan-bulan yang lain. Ikan oskar yang matang gonad ditemukan pada setiap bulan dalam setahun (Suryandari, Peneliti di Balai Penelitian Pemulihan dan Konservasi Sumber Daya Ikan, komunikasi pribadi). Berdasarkan hal tersebut, diketahui bahwa ikan oskar melakukan pemijahan sepanjang tahun.

Ikan oskar yang matang gonad ditemukan di seluruh stasiun pengamatan yang memiliki karakteristik perairan yang berbeda (Gambar 3). Hal ini membuktikan bahwa ikan ini telah beradaptasi dengan baik sehingga tidak hanya untuk bertahan hidup dan tumbuh secara somatik, namun juga telah mampu memanfaatkan hampir seluruh perairan dan tidak terpengaruh oleh musim untuk tumbuh secara gonadik. Ikan oskar memiliki penyebaran secara ruang dan waktu yang sangat luas di Waduk Ir. H. Djuanda (Tjahjo et al. 2009).
Selama pengamatan, ikan oskar yang matang gonad ditemukan dengan persentase yang lebih kecil daripada ikan yang belum matang gonad. Sebagian besar ikan yang tertangkap adalah ikan berukuran kecil yang belum mencapai ukuran dewasa (Gambar 4). Ikan-ikan muda yang nantinya siap menjadi induk tersedia dalam jumlah yang melimpah. Proporsi ikan yang matang gonad paling besar ditemukan pada bulan Desember dan Januari. Hal yang senada juga terlihat pada nilai IKG ikan oskar. Nilai IKG ikan oskar memiliki nilai paling tinggi pada bulan Desember dan Januari (Tabel 3). Fakta ini membawa pada kesimpulan bahwa puncak pemijahan terjadi pada bulan tersebut. Kematangan gonad ikan siklid di waduk dipengaruhi oleh suhu, musim hujan, dan ketinggian air (Duponchelle \& Legendre 2000; Peña-Mendoza et al. 2005).

Ukuran terkecil ikan oskar yang matang gonad di Waduk Ir. H. Djuanda (121 mm untuk ikan betina dan 125 mm untuk ikan jantan) ditemukan lebih besar daripada di Waduk Masaya, Nikaragua. Di Danau Masaya, ikan oskar ditemukan telah matang gonad pada ukuran $97 \mathrm{~mm}$ (Oldfield 2011). Ukuran pertama kali ikan matang gonad dapat dipengaruhi oleh faktor dalam berupa perbedaan spesies, umur, ukuran serta sifat-sifat fisiologi ikan dan faktor luar berupa makanan, karakter lingkungan dan adanya individu yang berlainan jenis kelamin. Faktorfaktor tersebut tidak diteliti lebih lanjut pada penelitian ini. Diduga di Waduk Ir. H. Djuanda, ikan oskar berkembang baik karena ketersediaan makanan yang berlimpah dan kemampuan mengatasi persaingan dengan jenis ikan lain. Diperlukan satu penelitian untuk membuktikan dugaan ini. 
Fekunditas total ikan oskar berkisar antara 729-3.299 butir. Tidak terdapat perbedaan yang besar antara nilai ini dengan fekunditas ikan oskar yang dilaporkan Purnamaningtyas \& Tjahjo (2010), yaitu 1.595-3.567 butir maupun fekunditas ikan golsom (Hemichromis elongatus) (511-4900 butir), yang juga merupakan ikan kelompok siklid, di Waduk Cirata (Hedianto \& Purnamaningtyas 2013). Fekunditas ini relatif kecil bila dibandingkan dengan ikan kelompok siprinid yang jumlah telurnya dapat mencapai puluhan ribu hingga ratusan ribu butir (Tampubolon et al. 2008, Iqbal \& Batool 2013). Tidak banyaknya jumlah telur ikan oskar terkait dengan sifat pengasuhan anak (parental care) yang dilakukan oleh ikan ini sebagai upaya memperbesar peluang kesuksestetasan telur dan sintasan keturunan yang dihasilkan.

Tipe pemijahan ikan diduga dari pola penyebaran diameter telur dalam gonad yang sudah matang dengan melihat modus penyebarannya. Modus sebaran ukuran diameter telur ikan oskar di Waduk Ir. H. Djuanda adalah modus ganda (Gambar 5). Ikan oskar adalah pemijah bertahap. Ikan oskar akan mengeluarkan telur yang matang secara bertahap pada satu siklus pemijahan. Hal ini dimaksudkan untuk memperbesar peluang anak-anak ikan memperoleh penjagaan induk yang baik sehingga memperbesar sintasan ikan. Tipe pemijahan yang sama juga dilaporkan pada ikan siklid lain seperti Oreochromis niloticus (Komolafe \& Arawomo 2007) dan Cichla Sp. (Gomiero \& Braga 2005).

\section{KESIMPULAN}

Ikan oskar memiliki nisbah kelamin yang seimbang. Ikan jantan dan betina pertama kali ditemukan matang gonad pada ukuran $125 \mathrm{~mm}$ dan $121 \mathrm{~mm}$. Pemijahan ikan oskar berlangsung sepanjang tahun yang puncaknya terjadi pada bulan Desember dan Januari dan ikan ini mampu memanfaatkan hampir seluruh perairan sebagai tempat pemijahan. Fekunditas total berkisar antara 729 3.299 butir. Ikan oskar merupakan ikan pemijah bertahap.

\section{DAFTAR PUSTAKA}

Albins, M. A., \& M. A. Hixon. 2008. Invasive Indo-Pacific lionfish, Pterois volitans, along the Bahamian Archipelago. Environmental Biology of Fishes 88: 305-309.

Barlow, G. W. 1976. The midas cichlid in Nicaragua. Investigations of the Ichthyofauna of Nicaraguan Lakes 23: 333-358. http:// digitalcommons.unl.edu/ ichthynicar/23 [Terhubung berkala] [19 Januari 2012].
Billman, E. J., B. J. Tjarks, \& M. C. Belk. 2011. Effect of predation and habitat quality on growth and reproduction of a stream fish. Ecology of Freshwater Fish 20: 102-113.

Duponchelle, F. \& M. Legendre. 2000. Oreochromis niloticus in Lake Ayame, Cote D'Ivoire: life history traits of a strongly diminished population. Cybium 24(2): 161-172.

Effendie, M. I. 1979. Metoda Biologi Perikanan. Penerbit Yayasan Dewi Sri. Bogor. 112pp.

Effendie, M. I. 2002. Biologi Perikanan. Ed rev. Penerbit Yayasan Pustaka Nusatama. Yogyakarta. 163pp.

Gomiero, L. M., \& F. M. S. Braga. 2004. Reproduction of species of the genus Cichla in a reservoir in southeastern Brazil. Brazilian Journal of Biology 64(3B): 613-624.

Hänfling B., P. Bolton, M. Harley, \& G. R. Carhalho. 2005. A molecular approach to detect hybridization between crusian carp (Carassius carassius) and non indigenous carp species (Carassius spp. And Cyprinus carpio). Freshwater Biology 50: 403-417.

Hedianto, D. A, \& S. E. Purnamaningtyas. 2012a. Penerapan kurva ABC (rasio kelimpahan/biomassa) untuk mengevaluasi dampak introduksi terhadap komunitas ikan di Waduk Ir. H. Djuanda. dalam Kartamihardja ES et al. (Editor). Prosiding Forum Nasional Pemacuan Sumber Daya Ikan III: POS-07.

Hedianto, D. A, \& S. E. Purnamaningtyas. 2012b. Perkembangan populasi ikan golsom (Hemichromis elongatus, Guichenot 1861) di Waduk Ir. H. Djuanda. In Kartamihardja ES et al. (Editor). Prosiding Forum Nasional Pemacuan Sumber Daya Ikan III: POS-08.

Hedianto, D. A, \& S. E. Purnamaningtyas. 2013. Biologi reproduksi ikan golsom (Hemichromis elongatus, Guichenot 1861) di Waduk Cirata, Jawa Barat. Bawal 5(3): 159-166.

Iqbal, Z., \& A. Batool. 2013. Fecundity of Labeo rohita (Teleostei: Cyprinidae) reared in earthen pond in Lahore. Canadian Journal of Pure \& Applied Sciences 7(2): 2.391-2.395.

Kartamihardja, E. S. 2008. Perubahan komposisi komunitas ikan dan faktor-faktor penting yang memengaruhi selama empat puluh tahun umur Waduk Djuanda. Jurnal Iktiologi Indonesia 8(2): 67-79. 
Komolafe, O. O., \& G. A. O. Arawomo. 2007. Reproductive strategy of Oreochromis niloticus (Pisces: Cichlidae) in Opa Reservoir, Ile-Ife, Nigeria. Revista de Biología Tropical 55(2): 595-602.

Kostecki C., S. Rochette, R. Girardin, M. Blanchard, N. Desroy, \& O. Le Pape O. 2011. Reduction of flatfish habitats as a consequence of the proliferation of an invasive mollusc. Estuarine, Coastal and Shelf Science 92: $154-160$

Lehtonen, T. K., J. K. McCrary, \& A. Meyer. 2010. Territorial aggression can be sensitive to the status of heterospecific intruders. Behavioural Processes 84: 598-601.

Nico, L.G., P. Sharp, \& T. M. Collins. 2011. Imported Asian swamp eels (Synbranchidae: Monopterus) in North American live food markets: Potential vectors of nonnative parasites. Aquatic Invasions 6(1): 69-76.

Oldfield, R. G. 2011. Gonad development in Midas cichlids and the evolution of sex change in fishes. Evolution and Development 13(4): 352-360.

Peña-Mendoza, B., J. L. Gómez-márquez, I. H. SalgadoUgarte, \& D. Ramírez-Noguera. 2005. Reproductive biology of Oreochromis niloticus (Perciformes: Cichlidae) at Emiliano Zapata dam, Morelos, Mexico. Revista de Biologia Tropical 53(3-4): 515-522.

Purnamaningtyas, S. E., \& D. W. H. Tjahjo. 2010. Beberapa aspek biologi ikan oskar (Amphilophus citrinellus) di Waduk Ir. H. Djuanda, Jatiluhur, Jawa Barat. Bawal 3(1): 9-16.
Putri, M. R. A., \& S. E. Purnamaningtyas. 2011. Distribusi ikan di Waduk Ir. H. Djuanda. In Simanjuntak CPH et al. (Editor). Prosiding Seminar Nasional Ikan VI, Cibinong. P. 401-407.

Supardi, U.S. 2013. Aplikasi Statistika dalam Penelitian. Ed rev. Change Publication. Jakarta. 436pp.

Tampubolon, P. A. R. P, \& M. F. Rahardjo. 2011. Pemijahan ikan sepat siam, Trichogaster pectoralis Regan 1910 di Danau Taliwang, Sumbawa. Jurnal Iktiologi Indonesia 11(2): 159-168.

Tampubolon, P. A. R. P, M. F. Rahardjo, D. S. Sjafei, \& C. P. H. Simanjuntak. 2008. Aspek pemijahan ikan motan, Thynnichthys thynnoides Bleeker 1852 (Famili Cyprinidae) di rawa banjiran Sungai Kampar Kiri, Riau. Jurnal Iktiologi Indonesia 8(1): 1-9.

Tjahjo, D. W. H., \& S. E. Purnamaningtyas. 2011. Keanekaragaman jenis ikan di Waduk Ir. H. Djuanda. In Simanjuntak CPH et al. (eds). Prosiding Seminar Nasional Ikan VI, Cibinong. p. 161-167.

Tjahjo, D. W. H., S. E. Purnamaningtyas, \& A. Suryandari. 2009. Evaluasi peran jenis ikan dalam pemanfaatan sumber daya pakan dan ruang di Waduk Ir. H. Djuanda, Jawa Barat. J.Lit.Perikan Ind. 15(4): 267-276.

Uzunova, E., \& S. Zlatanova. 2007. A review of the fish introductions in Bulgarian freshwater. Acta Ichthyologica et Piscatoria 37(1): 55-61. 
Lampiran 1. Karakteristik stasiun penelitian Appendix 1. The characteristic of research sampling location

\begin{tabular}{|c|c|c|c|c|}
\hline $\begin{array}{l}\text { No/ } \\
\text { No }\end{array}$ & $\begin{array}{l}\text { Stasiun/ } \\
\text { Station }\end{array}$ & & $\begin{array}{l}\text { Koordinat/ } \\
\text { Coordinate }\end{array}$ & $\begin{array}{l}\text { Karakteristik/ } \\
\text { Characteristic }\end{array}$ \\
\hline 1 & Cilalawi & $\begin{array}{l}\text { BT } \\
\text { LS }\end{array}$ & $\begin{array}{l}: 107^{\circ} 23,870^{\prime} \\
: 06^{\circ} 33.818\end{array}$ & $\begin{array}{l}\text { - } \text { Daerah inlet } \\
\text { - Sumber air dari Sungai Cilalawi } \\
\text { - Zona litoral } \\
\text { - Di sekitar lokasi terdapat tumbuhan air } \\
\text { - Perairan dipengaruhi aliran air dari Sungai Cilalawi }\end{array}$ \\
\hline 2 & Dam & $\begin{array}{l}\text { BT } \\
\text { LS }\end{array}$ & $\begin{array}{l}: 107^{\circ} 23,478^{\prime} \\
: 06^{\circ} 31,908^{\prime}\end{array}$ & $\begin{array}{l}\text { - Daerah genangan utama } \\
\text { - Zona litoral } \\
\text { - Dekat dengan bendungan } \\
\text { - Perairan relatif tenang }\end{array}$ \\
\hline 3 & Baras Barat & $\begin{array}{l}\text { BT } \\
\text { LS }\end{array}$ & $\begin{array}{l}: 107^{\circ} 21,786^{\prime} \\
: 06^{\circ} 32,157^{\prime}\end{array}$ & $\begin{array}{l}\text { - Daerah transisi } \\
\text { - Sumber air adalah gabungan dari Sungai Citarum } \\
\text { dengan genangan utama } \\
\text { - Di sekitar lokasi terdapat banyak KJA } \\
\text { - Zona limnetik. Kedalaman mencapai >50 m } \\
\text { - Perairan relatif tenang }\end{array}$ \\
\hline 4 & Pasir Astana & $\begin{array}{l}\text { BT } \\
\text { LS }\end{array}$ & $\begin{array}{l}: 107^{\circ} 19,732^{\prime} \\
: 06^{\circ} 30,428^{\prime}\end{array}$ & $\begin{array}{l}\text { - Daerah terlindung dan endapan } \\
\text { - Pernah ditetapkan sebagai daerah reservat } \\
\text { - Nutrien kecil } \\
\text { - Zona litoral } \\
\text { - Perairan relatif tenang }\end{array}$ \\
\hline 5 & Kerenceng & $\begin{array}{l}\text { BT } \\
\text { LS }\end{array}$ & $\begin{array}{l}: 107^{\circ} 18,385^{\prime} \\
: 06^{\circ} 32,639\end{array}$ & $\begin{array}{l}\text { - Daerah inlet-transisi } \\
\text { - Sumber air berasal dari Sungai Citarum } \\
\text { - Berarus sedang } \\
\text { - Di sekitar lokasi terdapat tempat pemancingan } \\
\text { - Zona litoral }\end{array}$ \\
\hline 6 & Jamaras & $\begin{array}{l}\text { BT } \\
\text { LS }\end{array}$ & $\begin{array}{l}: 107^{\circ} 18,211^{\prime} \\
: 06^{\circ} 35.563\end{array}$ & $\begin{array}{l}\text { - } \text { Daerah inlet } \\
\text { - Sumber air berasal dari Sungai Citarum } \\
\text { - Di sekitar lokasi terdapat banyak KJA } \\
\text { - Berarus sedang sampai besar } \\
\text { - Zona litoral }\end{array}$ \\
\hline
\end{tabular}

